Zeszyty Naukowe Szkoły Głównej Gospodarstwa Wiejskiego w Warszawie

Problemy Rolnictwa Światowego tom 19 (XXXIV), zeszyt 3, 2019: 97-107

DOI: 10.22630/PRS.2019.19.3.50

Joanna Szymańska ${ }^{1}$

Uniwersytet Ekonomiczny we Wrocławiu

\title{
Sytuacja na rynku ziemi rolniczej w wybranych krajach Europy Środkowo-Wschodniej (wybrane problemy)
}

\section{The Situation on the Market of Agricultural Land in Selected Countries of Central and Eastern Europe}

\begin{abstract}
Synopsis. Artykuł prezentuje ważniejsze czynniki wpływające zarówno na podaż, jak i na popyt ziemi rolniczej w takich krajach Europy Środkowo-Wschodniej, jak: Polska, Czechy, Słowacja, Węgry, Bułgaria, Rumunia, Litwa, Łotwa i Estonia. W opracowaniu poddano także analizie zmiany cen sprzedaży gruntów rolnych $\mathrm{w}$ badanych krajach za lata 2005-2015. Wskazano zarówno okresy wzrostu tych cen jak i ich spadku oraz główne czynniki, które miały wpływ na te zjawiska Stwierdzono, że w badanych krajach nie ukształtował się właściwie funkcjonujący rynek ziemi rolniczej.
\end{abstract}

Słowa kluczowe: Europa Środkowo-Wschodnia, ziemia rolnicza, podaż, popyt, cena

\begin{abstract}
The article presents the most important factors influencing both the supply and demand of agricultural land in such countries of Central and Eastern Europe as: Poland, the Czech Republic, Slovakia, Hungary, Bulgaria, Romania, Lithuania, Latvia and Estonia. The study also analyzed the changes in the sales prices of agricultural land in the analyzed countries for the years 2005-2015. Both the periods of growth of these prices and their decrease were indicated, as well as the main factors that influenced these phenomena. It was found that the properly functioning agricultural land market did not develop in the countries surveyed.
\end{abstract}

Key words: Central and Eastern Europe, agricultural land, supply, demand, price

JEL Classification: Q560, O180

\section{Wprowadzenie}

Ziemia pełni szczególną rolę w rolnictwie (oraz w leśnictwie). Stanowi nie tylko przestrzenną podstawę procesów produkcyjnych, ale także czynnie w nich uczestniczy. Jako czynnik produkcji rolnej ziemię cechują: niepomnażalność, nieprzemieszczalność, niezniszczalność; ziemia nie podlega amortyzacji, może się jednak przeobrażać, mają na to wpływ zarówno siły przyrody, jak i działalność człowieka. Ziemia ma w związku z tym istotny i trwały walor ekonomiczny (szerzej: Heijman i Krzyżanowska i Gędek i Kowakski, 1997; Kapusta, 2008; Szymańska, 2014).

\footnotetext{
${ }^{1}$ dr hab. inż., prof. UE we Wrocławiu, Katedra Ekonomiki i Organizacji Gospodarki Żywnościowej UE we Wrocławiu, 53-345 Wrocław, ul. Komandorska 118/120, e-mail: joanna.szymanska@ue.wroc.pl; https://orcid.org/0000-0002-9685-5235
} 
Zasoby ziemi rolniczej w państwach członkowskich Unii Europejskiej uznaje się za bardzo zróżnicowane, zarówno pod względem jakościowym (ukształtowanie terenu, jakość gleb, warunki klimatyczne itp.) jak i ilościowym (powierzchnia państw, miejsce rolnictwa w gospodarce danego kraju, tradycja, kultura rolna) (Majchrzak, 2015, s. 82). Europa należy do kontynentów o relatywnie wysokim rolniczym wykorzystaniu gruntów. Ponad połowę jej powierzchni zajmują użytki rolne (UR). Dwie trzecie ich areału przypada na grunty orne. Jakość gleb w Europie wykazuje stosunkowo duże zróżnicowanie. Czesść środkową kontynentu pokrywa kompleks gleb bielicowych i brunatnych, w jego części wschodniej występuje kompleks urodzajnych czarnoziemów (Matuszczak, 2013, s. 138).

Na zasoby ziemi rolniczej w UE w 2015 r. przypadało 184,5 mln ha. Spośród badanych krajów Europy Środkowo-Wschodniej (kraje EŚW) największą powierzchnią UR w 2015 r. dysponowała Polska (14,4 mln ha - jedne z największych zasobów w UE $)^{2}$, tylko nieco mniejszą Rumunia (13,8 $\mathrm{mln}$ ha), zdecydowanie mniejsza, kolejno: Wegry $(5,3 \mathrm{mln}$ ha), Bułgaria (5 mln ha), Czechy (4,2 $\mathrm{mln}$ ha), Litwa (3 mln ha), Łotwa i Słowacja (po 1,9 mln ha), a najmniejszą - Estonia (1 mln ha). W grupie analizowanych krajów EŚSW- w zakresie UR - w 2015 r., w porównaniu do roku 2005 można zaobserwować: spadek ich powierzchni geodezyjnej - w takich krajach, jak: Weegry (o 10,2 \%, do 5,3 mln ha), Polska (o 9,4\%, do 14,4 mln ha), Bułgaria (o 5,7\%, do $5 \mathrm{mln}$ ha), Rumunia (o 2,8\%, do $13,8 \mathrm{mln}$ ha) i Czechy (o 2,3\%, do 4,2 mln ha); wzrost areału UR - w małych krajach nadbałtyckich: Lotwa (o $11,8 \%$, do 1,9 mln ha), Estonia (o $11,1 \%$, do $1 \mathrm{mln}$ ha) i Litwa (o 7,1\%, do $3 \mathrm{mln}$ ha) (Dzun i Musiał, 2013, s. 7-9; Rocznik Statystyczny Rolnictwa...,2018). Spadek geodezyjnej powierzchni UR był następstwem ich przeznaczania na tereny komunikacyjne, osiedlowe, przemysłowe, użytki kopalne, zbiorniki wodne i na inne cele oraz zalesiana słabych rolniczo gleb. Należy to wiązać z rozwojem społeczno-gospodarczym, zwłaszcza przyspieszonym po przystąpieniu badanych krajów EŚW do UE. Z analizy danych statystycznych wynika, że, np. w Polsce w latach 2004-2008 geodezyjna powierzchnia „typowych” UR ${ }^{3}$ zmniejszyła się o 270 tys. ha, czyli o tyle, ile łącznie w latach 90 . XX w (Dzun, 2007, s. 51; Szymańska, 2012). Przyrost powierzchni UR (relatywnie niewielki) odnotowano jedynie $\mathrm{w}$ analizowanych małych krajach nadbałtyckich (Estonia, Litwa, Łotwa). W literaturze przedmiotu, niektórzy autorzy uznają, że wynika to z rozwoju ekstensywnych form produkcji rolnej, zwłaszcza upraw ekologicznych (Tarnowska, 2014). Stosunkowo duży wpływ na to zjawisko mają jednak różne formy wsparcia rolnictwa w ramach I i II filaru WPR UE, zwłaszcza dopłaty bezpośrednie.

Rynek ziemi rolniczej w analizowanych krajach EŚW, który zaczął się kształtować wraz z początkiem transformacji systemowej ich gospodarek, tworzy całokształt transakcji kupna-sprzedaży i dzierżawy ziemi rolniczej oraz warunków, w jakich one przebiegaja. Niezależnie funkcjonuje pozarynkowy obrót gruntami rolnymi (np. darowizny, spadki, zapisy o dożywocie), który pełni bardzo ważną rolę, zwłaszcza w polskim rolnictwie (ponad 98\% gospodarstw rolnych w Polsce funkcjonuje na bazie majątku przejętego przez następne pokolenie w rodzinie) (Rynek ziemi..., 2016).

\footnotetext{
${ }^{2}$ Większą powierzchnię UR niż w Polsce posiadają Francja (18\% łącznej powierzchni UR Unii Europejskiej) i Hiszpania (odpowiednio 16\%), a zbliżoną Niemcy, Wielka Brytania i Włochy (8-10\% łącznej powierzchni UR Unii Europejskiej).

${ }^{3}$ Autorka przyjęła, za W. Dzunem, jako powierzchnię geodezyjną „typowych” UR łączną powierzchnię gruntów ornych, sadów i TUZ, mimo zmian, jakie zostały wprowadzone Rozporządzeniem Ministra Rozwoju Regionalnego i Budownictwa z dnia 29 marca 2001 r. w sprawie ewidencji gruntów i budynków (Dz. U. nr 38, poz. 454)
} 
Podaż gruntów rolnych warunkuje specyfika lokalnego rynku ziemi, która może stanowić naturalną barierę $\mathrm{w}$ obrocie gruntami rolnymi (istnienie nierównowagi popytowopodażowej, nadpodaży lub niezaspokojonego popytu na ziemię). W tym aspekcie należy brać pod uwagę postawy właścicieli tych gruntów (potrzeba sprzedaży czy dzierżawy ziemi) i czynniki warunkujące te postawy (np. wpływ dopłat bezpośrednich i innych płatności, znaczenie renty kapitałowej z ziemi i inne).

Do czynników kreujących popyt na ziemię zalicza się, z kolei potrzeby producentów rolnych (chęć powiększenia gospodarstwa) oraz potrzeby osób chcących lokować wolne środki finansowe $\mathrm{w}$ nieruchomości gruntowe, usytuowane zwłaszcza w sąsiedztwie wielkich aglomeracji oraz $w$ rejonach atrakcyjnych turystycznie (szansa na przekwalifikowanie gruntów na działalność nierolnicza). Na sytuację na rynku ziemi oddziałuje ponadto „kurcząca się” geodezyjna powierzchnia UR (przeznaczanie ziemi na inne cele niż rolne, np. przemysłowe), a także zmiany przepisów prawnych w zakresie obrotu gruntami rolnymi (Rynek ziemi...2016).

Celem opracowania jest przedstawienie i próba oceny czynników wpływających na podaż, popyt i ceny ziemi rolniczej w takich krajach Europy Srodkowo-Wschodniej, jak: Polska, Czechy, Słowacja, Węgry, Bułgaria, Rumunia, Litwa, Łotwa i Estonia.

\section{Dane i metody}

Do przygotowania artykułu wykorzystano wybrane pozycje z literatury przedmiotu, specjalistyczne opracowania oraz dane statystyki powszechnej dotyczące podaży, popytu i cen ziemi rolniczej w wybranych krajach EŚW. Dane te są zamieszczane w rocznikach statystycznych pt. „Roczniki statystyczne rolnictwa” oraz w specjalistycznych czasopismach pt. „Rynek ziemi rolniczej”. Horyzont czasowy badań obejmuje lata 20052015.

W opracowaniu wykorzystano metody badawcze typu „desk research”: opisową, analizy porównawczej, matematyczne.

\section{Podaż, popyt i ceny ziemi rolniczej}

Rynek ziemi rolniczej kształtuje się pod wpływem odbywających się na nim transakcji kupna-sprzedaży gruntów. W określony sposób może oddziaływać na ten rynek przekazywanie gruntów w czasowe użytkowanie w zamian za określoną opłatę, bez przeniesienia prawa własności, czyli dzierżawa gruntów. Na zasięg i charakter obrotu gruntami rolnymi mają też wpływ zmiany własnościowe dokonywane w formie aktów nierynkowych.

Transformacja systemowa w Europie Środkowo-Wschodniej rozpoczęła dynamiczne przeobrażenia w sektorze rolnym. Polegały one na prywatyzacji i restrukturyzacji majątku sektora uspołecznionego (państwowego i spółdzielczego) w rolnictwie. Zaczął się proces przywracania (restytucji) prywatnej własności ziemi rolniczej w krajach EŚW. Jak się podkreśla w literaturze przedmiotu, proces ten odbywał się głównie dwiema drogami:

- Pierwsza droga - przywracanie prawa własności do ziemi jej byłym właścicielom lub ich spadkobiercom (Czechy, Słowacja, Węgry, Estonia, Litwa, Łotwa, Rumunia). 
- Druga droga - nadanie praw własności do ziemi jej użytkownikom (Bułgaria) (Zadura, 2005, s. 32).

Należy zaznaczyć, że spośród badanych krajów EŚW tylko w Polsce, w okresie poprzedzającym tę transformację, rolnictwo indywidualne użytkowało zdecydowaną większość gruntów rolnych $-76 \%$ (pozostały odsetek - sektor uspołeczniony). W pozostałych badanych krajach (Bułgaria, Czechy, Słowacja, Węgry, Estonia, Litwa, Łotwa, Rumunia), przed 1989 r. zdecydowana większość areału gruntów rolnych była natomiast zagospodarowana przez sektor uspołeczniony.

Na Węgrzech, Łotwie oraz w Estonii i Bułgarii beneficjentami tej restytucji zostały w wielu przypadkach - osoby, które utraciły związek z rolnictwem, bardzo często będące już w wieku emerytalnym i mieszkające w miastach. W Czechach, na Słowacji, w Estonii i Bułgarii nie wszyscy beneficjenci ziemi rolniczej wyrażali chęć samodzielnego prowadzenia gospodarstw rolnych (Zadura, 2005, s. 32). Ponadto w Bułgarii, w Czechach i na Słowacji, w początkowym okresie restytucji, pojawiły się problemy ze stosunkowo szybkim technicznym wydzieleniem gruntów prywatnych z gruntów byłych kolektywnych czy państwowych gospodarstw rolnych. Zasadniczym ograniczeniem okazały się koszty (stosunkowo wysokie) takiego przedsięwzięcia, co - zdaniem Autorki - należy ocenić krytycznie, w kontekście kształtowania się rynku ziemi rolniczej.

Relatywnie niska liczba przeprowadzonych transakcji kupna-sprzedaży gruntów rolnych w Czechach, na Słowacji i Węgrzech, w Estonii i Bułgarii w połowie pierwszego dziesięciolecia lat 2000 nie doprowadziła do powstania rynku ziemi, jak podkreśla A. Zadura. W zdecydowanej większości właściciele tych gruntów wydzierżawili je, z uwagi na brak chętnych do odkupu (niski czynsz dzierżawny zniechęcał do zakupu ziemi). Taka sytuacja była spowodowana zwłaszcza nadpodażą ziemi rolniczej, ale istotne znaczenie przypisuje się także stosunkowo wysokim kosztom transakcyjnym, związanym ze sprzedażą tych gruntów (opłaty notarialne, podatki i inne koszty administracyjne). Łącznie te koszty stanowiły 10$30 \%$ wartości transakcji (najwyższe na terenie Węgier, sięgające nawet $30 \%$ tej wartości) (Zadura, 2005a, s. 32). W efekcie dominującym modelem zagospodarowania gruntów rolnych w Czechach, na Słowacji, Litwie, Łotwie, w Bułgarii i Estonii oraz częściowo na Węgrzech stały się prorynkowo zorientowane spółdzielnie produkcyjne bądź byłe państwowe gospodarstwa rolne przekształcone w spółki prawa handlowego. Średnio użytkują one 70\% ogólnej powierzchni gruntów rolnych w tych krajach. Jednostki te dzierżawią ziemię rolniczą od drobnych właścicieli. W Czechach i na Słowacji ponad 90\% ogólnej powierzchni gruntów rolnych stanowily (początek lat 2000) grunty dzierżawione, przy czym w Czechach - 95\%, najwięcej w Europie. W Estonii i na Litwie ten wskaźnik był niższy i mieścił się (połowa lat 2000) w przedziale 50-60\%. Na Łotwie i w Bułgarii udział dzierżawionych gruntów rolnych w ogólnej powierzchni użytków rolnych okazał się jeszcze niższy, nie przekraczał w analogicznym okresie 25\% (Zadura, 2005a; Zadura, 2005b).

Efektywność zagospodarowania tych gruntów przez gospodarstwa wielkoobszarowe analitycy oceniają jako stosunkowo wysoka, zdecydowanie wyższą od tej, jaką mogłyby przeciętnie uzyskać drobne gospodarstwa indywidualne. Ze względów „,czysto ekonomicznych" (w wąskim ujęciu), można ocenić to korzystnie, natomiast w szerokim aspekcie rozważań (społeczno-ekonomicznym i środowiskowym (ekologicznym)), czyli w duchu idei rozwoju zrównoważonego - Autorka ocenia to jako niekorzystne zjawisko. Należy się zgodzić z A. Zadura, że restytucja prawa własności nie zmieniła, w istotny sposób, struktur organizacyjnych użytkowania ziemi rolniczej w wielu krajach EŚW, zwłaszcza w Czechach, na Słowacji i Węgrzech (Zadura, 2005a; Zadura, 2009, s. 46). 
Jednak skoncentrowanie dzierżawy gruntów rolnych w użytkowaniu gospodarstw wielkoobszarowych to bardzo istotny hamulec powstania prywatnego rynku ziemi, zdaniem analityków. Autorka podziela ten pogląd. W większości krajów EŚW, gdzie występuje tego typu zjawisko (Czechy, Słowacja, Węgry, Bułgaria) lub nadmiar siły roboczej w rolnictwie (część Rumunii) w obrocie gruntami rolnymi, w połowie pierwszej dekady lat 2000, uczestniczyło nie więcej niż 2-5\% ogółu gospodarstw (Zadura, 2006, s.31). Należy to ocenić jako zjawisko niekorzystne, nie sprzyjające umacnianiu się rynku ziemi rolniczej. Natomiast w Polsce, uwarunkowania historyczne przyczyniły się do tego, że preferowana jest własność w rolniczym użytkowaniu gruntów (szerzej: Marks-Bielska, 2010; Tańska-Hus, 2009). Wśród czynników od lat oddziałujących na sytuację na krajowym rynku ziemi rolniczej niezmiennie podstawowe znaczenie ma rodzinny charakter zdecydowanej większości gospodarstw rolnych (w Polsce ponad 98\% tych gospodarstw funkcjonuje na bazie majątku przejętego przez następne pokolenie w rodzinie) (Rynek ziemi..., 2016). Obrót ziemią rolniczą w Polsce odbywał się głównie poza rynkiem (tzw. obrót rodzinny) (Sikorska, 2010). W efekcie o przemianach agrarnych w polskim rolnictwie nieprzerwanie decydują postawy właścicieli gospodarstw, wśród których wzrasta liczba rodzin utrzymujących się głównie ze źródeł nierolniczych - 66\% (korzystanie $\mathrm{z}$ taniego ubezpieczenia w KRUS, dopłaty bezpośrednie, funkcje rezydencyjne siedliska, rosnące znaczenie renty kapitałowej, która w odniesieniu do ziemi znacznie przekracza oprocentowanie lokat bankowych i funduszy inwestycyjnych, wg danych IERiGŻ PIB z 2011 r.) (Czyżewski i Henisz-Matuszczak, 2004; Rynek ziemi...2016). Wymienione ograniczenia podażowe należy uzupełnić o specyfikę lokalnego rynku ziemi, która stanowi naturalną barierę w obrocie gruntami rolnymi (istnienie nierównowagi popytowo-podażowej, np. w Polsce rozmieszczenie gruntów z Zasobu Własności Rolnej Skarbu Państwa ZWRSP)). Nie jest to, także zdaniem Autorki, korzystne zjawisko dla pożądanego modelu rynku ziemi rolniczej. Przed przystąpieniem do Unii Europejskiej (2003r.) średnia powierzchnia UR w gospodarstwie w Polsce wynosiła 6,6 ha i była jedną $\mathrm{z}$ najniższych w Unii Europejskiej. Przeciętnie w całej ówczesnej UE (UE-25) ten wskaźnik był ponad 2-krotnie wyższy. Spośród badanych krajów EŚW mniejsza powierzchnia indywidualnych gospodarstw rolnych była w analizowanym okresie na Węgrzech (5,6 ha). Rozpowszechnienie dzierżaw ma na celu przyspieszenie procesów koncentracji w rolnictwie. W Polsce skala zjawiska dzierżaw ziemi rolniczej jest dodatnio skorelowana $\mathrm{z}$ wielkością użytkowanej ziemi. Wśród gospodarstw o obszarze powyżej 30 ha UR liczba dzierżawców stanowiła ponad $70 \%$ pod koniec 2012 r. Z kolei częstotliwość występowania dzierżaw była zdeterminowana sytuacją popytowo-podażową. $\mathrm{W}$ pasie ziem zachodnich i północnych ziemię rolniczą dzierżawiło w tym okresie co piąte gospodarstwo indywidualne, zaś na obszarach południowo-wschodniej Polski - co dziesiąte. O procesie koncentracji w rolnictwie decyduje przede wszystkim skłonność części użytkowników do likwidacji gospodarstwa lub zmniejszenia jego areału, jak wynika $\mathrm{z}$ badań i analiz prowadzonych przez IERiGŻPIB (Rynek ziemi...,2016). W 2015 r. średni obszar gospodarstw rolnych w Polsce wzrósł do 10 ha UR, co Autorka także ocenia jako korzystne zjawisko.

Do czynników kreujących popyt na ziemię zalicza się, z kolei potrzeby producentów rolnych (chęć powiększenia gospodarstwa) oraz potrzeby osób chcących lokować wolne środki finansowe $\mathrm{w}$ nieruchomości gruntowe, usytuowane zwłaszcza w sąsiedztwie wielkich aglomeracji (szansa na przekwalifikowanie gruntów na działalność nierolnicza) oraz w rejonach atrakcyjnych turystycznie. Na sytuację na rynku ziemi oddziałuje ponadto 
„kurcząca się” geodezyjna powierzchnia UR (rozwój terenów zurbanizowanych i zindustrializowanych), a także zmiany przepisów prawnych w zakresie obrotu gruntami rolnymi (okresy karencji w sprzedaży ziemi rolniczej obcokrajowcom). „Wypadanie” dobrej ziemi z rolnictwa (rozwój aglomeracji miejskich: budownictwo mieszkaniowe, przemysłowe, handowo-usługowe), Autorka ocenia jako bardzo niekorzystne zjawisko społeczno-ekonomiczne i środowiskowe (ekologiczne), pozostające w sprzeczności z ideą rozwoju zrównoważonego obszarów wiejskich.

Z kolei wśród cech kształtujących konkurencyjność ziemi rolniczej, największą rolę pełni jej jakość i położenie (Urban, 2006, s. 459). Wymienione uwarunkowania oraz inne, do których A. Matuszczak zalicza zwłaszcza zaszłości historyczne, skutkują ogromnym zróżnicowaniem zaangażowania czynnika ziemi w procesy produkcyjne (Matuszczak, 2013, s. 138).

W analizowanych krajach EŚW ceny sprzedaży ziemi rolniczej w latach 2005-2015 były znacznie zróżnicowane (rys. 1). Stosunkowo najwyższe, w początkowym badanym okresie (2005 r.), notowano na Łotwie (2301 EUR/ha), a tylko niewiele niższe na rynku prywatnym w Polsce (odpowiednio - 2108 EUR/ha; na rynku z udziałem ANR były niższe - 1454 EUR/ha). Na trzecim miejscu pod tym względem uplasowały się Czechy (1621 EUR/ha). Relatywnie najniższe ceny sprzedaży gruntów rolnych w 2005 r. były w Estonii (486 EUR/ha) i niewiele wyższe na Litwie (536 EUR/ha). Dla pozostałych badanych krajów (Bułgaria, Rumunia, Słowacja, Węgry) ${ }^{4}$ te ceny należały do przedziału 742-982 EUR/ha. Dla porównania, w krajach „starej Unii”, według danych Eurostatu, ceny sprzedaży gruntów rolnych były zdecydowanie wyższe, na przykład (2005 r.) w Holandii, Irlandii czy w Belgii (odpowiednio: 30235 EUR/ha, 30000 EUR/ha i 22053 EUR/ha). Relatywnie wysoki poziom cen gruntów rolnych w krajach „starej Unii” odzwierciedlał nie tylko wartość produkcyjną ziemi, ale również jej wartość dodaną, która wynikała z samego tytułu posiadania użytkowania ziemi. Tytuł ten umożliwia czerpanie pożytków $\mathrm{z}$ instrumentów wsparcia rolnictwa w ramach wspólnej polityki rolnej UE i renty z lokaty kapitału w nieruchomość rolną (Zadura, 2005). Zróżnicowanie analizowanych cen występowało nie tylko między poszczególnymi krajami, ale także między okresami badań. W latach 2005-2008 w prawie wszystkich badanych krajach EŚW wzrosły ceny analizowanych gruntów. Średnia dynamika wzrostu tych cen należała do przedziału 19,5$30,7 \%$. Wyjątkiem okazała się Łotwa, gdzie te ceny się obniżyły, ale tylko w latach 20052006, zaś w 2007 r. pozostały na poziomie z poprzedniego roku- rys. 1 . W Polsce wzrost cen ziemi rolniczej obserwuje się od początku lat $90 \mathrm{XX} \mathrm{w,} \mathrm{a} \mathrm{zwłaszcza} \mathrm{od} \mathrm{czasu}$ przystąienia do Unii Europejskiej. W połowie drugiej dekady lat 2000, w porównaniu do stanu z roku 1992 jej średnia cena wzrosła prawie 50-krotnie. Zakup ziemi rolniczej okazał się dobrym sposobem lokowania kapitału. Stopa zwrotu kapitału sięgnęła kilkuset procent (de Jesus, Sławińska, 2016). Z analizy danych EUROSTST i GUS wynika, że po przystapieniu Polski do Unii Europejskiej znacznie nasiliła się tendencja wzrostowa cen ziemi, która zaznaczyła się już w 2003 r. (dot. rynku prywatnego obrotu ziemią rolniczą w Polsce; wpływ mechanizmów wspólnej polityki rolnej UE i innych polityk Wspólnoty; wzrost liczby umów kupna-sprzedaży ziemi, z 45,5 w 2003 r. do 53 w 2007 r., liczonych na 1000 gospodarstw) (Czyżewski, 2010; Szymańska, 2013; Rynek ziemi..., 2016). Analogiczne zjawisko dotyczyło pozostałych analizowanych krajów. Badając, z kolei

\footnotetext{
${ }^{4}$ Bułgaria i Rumunia przystąpiły do Unii Europejskiej w 2007 r., zaś pozostałe badane kraje w 2004 r.
} 
zmienność cen ziemi rolniczej w Polsce, J. Maśniak stwierdza wpływ polityki sektorowej państwa na to zjawisko i za najistotniejszy czynnik uznaje włączenie Polski do systemu płatności obszarowych w rolnictwie po wstapieniu do Unii Europejskiej. W efekcie generowanie dodatkowego dochodu przez ziemię rolniczą przyczyniło się do wzrostu jej realnych cen rynkowych (Maśniak, 2013).

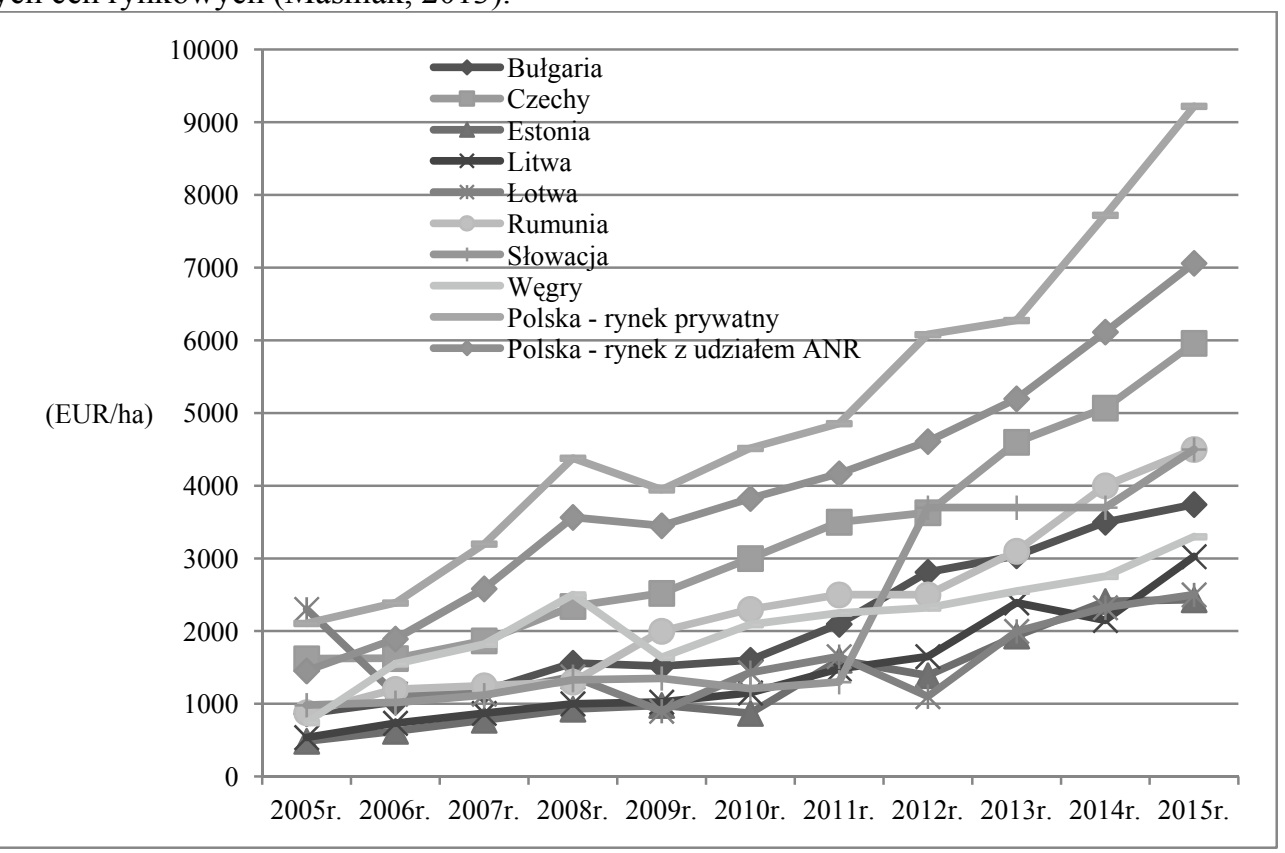

Rys. 1. Średnie ceny gruntów rolnych w wybranych krajach EŚW za lata 2005-2015 (EUR/ha)

Fig. 1. Average prices of agricultural land in selected countries of Central and Eastern Europe for the years 20052015 (EUR / ha)

Źródło: opracowanie własne na podstawie: Rynek ziemi..., 2006-2016. Warszawa: IERiGŻ-PIB.

Do podobnego wniosku dochodzi A. Tarnowska, analizując sytuację na rynku ziemi rolniczej nowych członków Unii Europejskiej. ${ }^{5}$ Za sprawą dopłat bezpośrednich, ziemia stała się zasobem cenniejszym niż we wcześniejszym okresie. Oprócz przychodów z produkcji płodów rolnych, grunty zaczęły generować dodatkowe przychody (Tarnowska, 2014).

Rok 2009 przyniósł na rynkach nieruchomości rolnych większości krajów Europy wyhamowanie wzrostu cen gruntów rolnych lub ich spadek, zjawisko to dotyczy także prawie wszystkich badanych krajów EŚW, poza Rumunią. Analizowane ceny obniżyły się (w 2009 r., w porównaniu z rokiem 2008) w/na: Bułgarii (o 2,7\%), Łotwie (o 34,5\%), Wegrzech (o $34,4 \%$ ), Polsce (na rynku prywatnym o $9,9 \%$, a na rynku z udziałem ZWR SP - o 3,2\%; spadła liczba zawartych umów kupna-sprzedaży ziemi, do 45,8 na 1000

\footnotetext{
${ }^{5}$ Nowe kraje członkowskie (NKC 12): Bułgaria, Cypr, Estonia, Litwa, Łotwa, Malta, Polska, Republika Czeska,
} Rumunia, Słowacja, Słowenia, Węgry. 
gospodarstw w 2009 r.). Analitycy uznaja, że było to skutkiem wpływu globalnego kryzysu finansowego i dotyczyło tych krajów EŚW, które odnotowały wysoki spadek PKB. Jednocześnie, w niektórych państwach Europy, w związku z ograniczoną podażą gruntów rolnych lub dostępem do rynku analizowanych gruntów inwestorów spoza rolnictwa, utrzymywał się wzrostowy trend cen gruntów rolnych (Zadura, 2010, s. 44).

W kolejnym badanym okresie (lata 2010-2015) obserwuje się powrót większości analizowanych cen na ścieżkę wzrostowego trendu (rys. 1). Srednia dynamika wzrostu tych cen należała do przedziału $16,3-39 \%$. Ceny gruntów rolnych obniżyły się tylko w Estonii (w latach 2009-2010 oraz w latach 2011-2012), na Słowacji (lata 2009-2010), Lotwie (w latach 2011-2012) i Litwie (w latach 2013-2014).

J. Maśniak, badając ceny ziemi rolniczej w Polsce w latach 1992-2011 stwierdza, że w okresach dobrej koniunktury te ceny wzrastały znacznie szybciej niż w fazach spadkowych i okresach stagnacji. $Z$ tych badań wynika także, że ceny ziemi rolniczej kształtowały się w sposób typowy dla dóbr kapitałowych (Maśniak, 2013). Na podstawie analiz prowadzonych przez IERiGŻ PIB można stwierdzić, że na średnią cenę sprzedaży gruntów rolnych w Polsce miał w tym okresie wpływ stosunkowo bardzo dynamiczny wzrost cen gruntów położonych $\mathrm{w}$ okolicach dużych miast $\mathrm{i}$ w miejscowościach atrakcyjnych turystycznie (renta położenia; w 2015 r. liczba zawartych umów kupna-sprzedaży ziemi wzrosła do 66,7 na 1000 gospodarstw) (Rynek ziemi..., 2016; Szymańska, 2014). Analogiczna sytuacja ma miejsce w Czechach, na Słowacji, w Rumunii i na Wegrzech, według J. Bańskiego (Bański, 2017).To sprawia, że rynkowe ceny tych gruntów są w coraz mniejszym stopniu uzależnione od ich wartości bonitacyjnej.

Szczegółowa analiza cen sprzedaży gruntów rolnych w latach 2005-2015 pozwala stwierdzić, że dla wszystkich badanych krajów EŚW ukształtowały się rosnące trendy tych cen, zakłócane, w większości przypadków, krótkotrwałymi ich spadkami lub wyhamowaniem. Należy się zgodzić z A. Sikorską, która uważa, że wzrastające ceny ziemi wzmacniają kapitałowe znaczenie posiadanych gruntów rolnych i podnoszą ich atrakcyjność, jako właściwości majątkowej (Sikorska, 2010).

Rosnąca konkurencja na rynku ziemi rolniczej w Europie Zachodniej - spowodowana także wykorzystaniem surowców rolniczych na cele energetyczne - sprawia, że ponadnarodowe korporacje i fundusze inwestycyjne kupuja, dzierżawią lub uzyskuja możliwość użytkowania gruntów w krajach o relatywnie niskich cenach ziemi, jak podają analitycy za danymi Banku Światowego, m.in. w krajach nadbaltyckich (Litwa, Łotwa, Estonia) $^{6}$ (Zadura, 2010). Sprzyjające warunki udzielania pożyczek na zakup ziemi przez czeskie banki, jakie zaistniały w 2015 r. i parę lat wcześniej sprawiły, że wielcy dzierżawcy zawierali coraz więcej transakcji kupna-sprzedaży, których przedmiotem były grunty rolne. Potwierdza to zmniejszający się odsetek dzierżawionej ziemi. W $2013 \mathrm{r}$. stanowił on $76 \%$, wobec $95 \% \mathrm{w}$ początkowym okresie restytucji prawa własności. Wysokie ceny gruntów rolnych w Europie Zachodniej, w sytuacji kurczących się geodezyjnych zasobów UR i coraz bardziej nakierowanej na ochronę środowiska naturalnego wspólnej polityki rolnej UE sprawiaja, że producenci rolni z tych krajów są zainteresowani zakupem stosunkowo taniej ziemi rolniczej $\mathrm{w}$ krajach Europy Środkowo-Wschodniej, jak wynika $\mathrm{z}$ analiz IERiGŻ PIB. Można przewidywać, zdaniem Autorki, utrzymanie się podobnego zjawiska.

\footnotetext{
6 Na przykład litewsko-fińsko-szwedzka firma inwestycyjno-produkcyjna Agrowill AB, pod koniec 2009 r., użytkowała łącznie 35 tys. ha gruntów rolnych na Litwie i w Estonii, z czego 80\% areału stanowiły grunty dzierżawione (szerzej: Zadura, 2010, s. 52).
} 


\section{Podsumowanie}

Przyjęte przez decydentów założenie, że restytucja prawa własności do ziemi rolniczej, będąca następstwem procesu transformacji systemowej w rolnictwie krajów EŚW, spowoduje powstanie prężnie działającego jej rynku i poprzez to - silnych gospodarstw rodzinnych okazało się nieuzasadnione (Rynek ziemi..., 2005, s. 32). Należy się zgodzić z tym stwierdzeniem. Zwłaszcza w Czechach, na Słowacji, w Bułgarii oraz na Węgrzech pojawiły się zarówno problemy natury technicznej, związane z wydzielaniem gruntów prywatnych $\mathrm{z}$ gruntów byłych uspołecznionych gospodarstw rolnych jak i problemy ekonomiczne (relatywnie wysokie koszty takich operacji). Dodatkowo ujawniły się w tych krajach oraz na Łotwie i w Estonii bariery społeczne związane z utratą związku beneficjentów tej restytucji $\mathrm{z}$ rolnictwem, wynikające $\mathrm{z}$ ich zaawansowanego wieku $\mathrm{i}$ miejsca zamieszkania. Dominującym modelem zagospodarowania gruntów rolnych w tych krajach stały się prorynkowo zorientowane spółdzielnie produkcyjne lub byłe państwowe gospodarstwa rolne, które zostały przekształcone w spółki prawa handlowego. Indywidualne (rodzinne) gospodarstwa rolne pełnią tam mało znaczącą rolę, odmiennie niż w Polsce, co wynika z historycznych uwarunkowań.

W takich krajach, jak: Bułgaria, Węgry, Rumunia, częściowo Czechy i Słowacja ukształtowała się niepożądana struktura agrarna. Nowopowstałe gospodarstwa prywatne okazały się stosunkowo małe (rozdrobnienie struktury agrarnej), zwłaszcza na Węgrzech i w Rumunii. Od paru lat analitycy obserwują tam jednak ubytek liczby gospodarstw rodzinnych oraz wzrost dużych przedsiębiorstw produkcyjnych (Bański, 2017).

Spośród badanych krajów EŚW tylko w Polsce, w minionym systemie społecznogospodarczym wiodąca rolę w użytkowaniu gruntów rolnych pełniło rolnictwo indywidualne, w pozostałych krajach - rolnictwo uspołecznione. Po likwidacji własności uspołecznionej w polskim rolnictwie znacząco wzrosła podaż gruntów. Zjawisko to miało jednak regionalny charakter, ściśle skorelowany z usytuowaniem tego typu gospodarstw. W efekcie w regionach, gdzie gospodarstwa sektora uspołecznionego pełniły marginalną rolę utrzymywał się niezaspokojony popyt na ziemię, zwłaszcza w okresie koniunktury w rolnictwie.

Ceny sprzedaży ziemi rolniczej (prywatny obrót) w analizowanych krajach EŚW w latach 2005-2015 okazały się znacząco zróżnicowane, przeciętnie w całym tym okresie najwyższe były w Polsce, zaś najniższe w Estonii. W analizowanym czasie zaobserwowano ukształtowanie się rosnącego trendu tych cen, który zakłócały krótkie okresy ich wyhamowania lub spadku. Istotny wpływ na to zjawisko miał światowy kryzys finansowy. $\mathrm{Z}$ kolei wzrost cen sprzedaży gruntów rolnych $\mathrm{w}$ badanych krajach $\mathrm{w}$ określonych przedziałach czasowych należy łączyć z występowaniem koniunktury w rolnictwie oraz z wpływem mechanizmów wspólnej polityki rolnej UE (dopłaty bezpośrednie i inne płatności), w sytuacji zmniejszającej się powierzchni geodezyjnej UR i zakończonych, w niektórych z tych krajów, okresów karencji sprzedaży gruntów rolnych dla obcokrajowców. Określony wpływ na wzrost tych cen mają również rosnące wymogi w zakresie gospodarowania ziemią, w aspekcie postępującej ekologizacji rolnictwa, co sprawia, że można przewidywać dalszy wzrost cen ziemi rolniczej w krajach Europy ŚrodkowoWschodniej, a szerzej w całej Unii Europejskiej. 


\section{Literatura}

Bański, J. (2017). Zmiany własnościowe użytków rolnych w wybranych krajach Europy Środkowej (Ownership Changes of Agricultural Land in Selected Countries of Central Europe). Wieś i Rolnictwo, 1(174), 7-22. DOI: $10.7366 /$ wir012017/01.

Czyżewski, A. (2010). Relacje między otoczeniem makroekonomicznym a rolnictwem w okresie transformacji gospodarki Polski (1990-2009) (Relationship between Macroeconomics Environment and Agriculture in the Period of the Transformation of Poland's Economy 1990-2009). Roczniki Naukowe SERiA, 12(1), 23-28.

Czyżewski, A., Henisz-Matuszczak, A. (2004). Rolnictwo Unii Europejskiej i Polski (Agriculture of the European Union and Poland). Wydawnictwo Akademii Ekonomicznej w Poznaniu. Poznań.

de Jesus, I.M., Sławińska, N. (2016). Kształtowanie się cen gruntów rolnych w Polsce na tle wybranych krajów Unii Europejskiej (Price Formation of Agricultural Land in Poland on The Background of Selected Countries of The European Union). Prace Naukowe Uniwersytetu Ekonomicznego we Wrockawiu, 454, 45 51.

Dzun, W. (2007). Gospodarowanie zasobami ziemi rolniczej w Polsce (Agricultural Land Resources Management in Poland). Wieś i Rolnictwo, 2(135).

Dzun, W., Musiał, W. (2013). Zagospodarowanie ziemi rolniczej w Polsce w okresie przed- i poakcesyjnym w ujęciu regionalnym (The Regional Dimension of Agricultural Land Development in Poland in Pre- and Postaccession Periods). Wieś i Rolnictwo, 4(161), 62-78.

Heijman, W., Krzyżanowska, Z., Gędek, S., Kowalski, Z. (1997). Ekonomika rolnictwa. Zarys teorii (Agricultural Economics. An Outline of the Theory). Wydawnictwo Fundacja Rozwoju SGGW. Warszawa.

Kapusta, F. (2008). Agrobiznes (Agribusiness). Wydawnictwo CDiI Difin. Warszawa.

Majchrzak, A. (2015). Ziemia rolnicza w krajach Unii Europejskiej w warunkach ewolucji wspólnej polityki rolnej (Farmland in the EU as a Result of the Evolution of the CAP). Wydawnictwo Naukowe PWN Warszawa.

Marks-Bielska, R. (2010). Rynek ziemi rolniczej w Polsce - uwarunkowania i tendencje rozwoju (Agricultural Land Market in Poland - Conditions and Development Trends). Wydawnictwo Uniwersytetu WarmińskoMazurskiego w Olsztynie. Olsztyn.

Maśniak, J. (2013). Koniunktura gospodarcza a rynek ziemi rolniczej (Business Cycle and Agricultural Land Market). Roczniki Naukowe SERiA, 15(3), 224-228.

Matuszczak, A. (2013). Zróżnicowanie rozwoju rolnictwa w regionach Unii Europejskiej w aspekcie jego zrównoważenia (Diversification of Agricultural Development in Regions of the European Union in the Aspect of its Sustainability). Wydawnictwo Naukowe PWN. Warszawa

Obwieszczenie Marszałka Sejmu Rzeczypospolitej Polskiej z dnia 26 maja 2017 r. (Dz. U. 2017, poz. 1161) w sprawie ogłoszenia jednolitego tekstu ustawy o ochronie gruntów rolnych i leśnych. Pobrane 15 listopada 2018 z http:// dziennikustaw.gov.pl/du/2017/1161/1.pdf.

Rocznik Statystyczny Rolnictwa 2017 (Statistical Yearbook of Agriculture 2017). (2018). Warszawa: GUS.

Rynek ziemi ziemi rolniczej (Agricultural Land Market). (2016). Analizy Rynkowe, 19. Warszawa: IERiGŻ-PIB.

Sikorska, A. (2010). Zróżnicowanie regionalne w rozwoju rolnictwa oraz jego wpływ na problemy ekonomiczne i społeczne obszarów wiejskich (Regional Diversity in Agricultural Development and its Impact on Economic and Social Problems of Rural Areas). W: A. Kowalski (red.). Ekonomiczne i społeczne uwarunkowania rozwoju polskiej gospodarki żywnościowej po wstąpieniu Polski do Unii Europejskiej (Synteza) (s. 153164). Warszawa: IERiGŻ-PIB.

Szymańska, J. (2012). Gospodarowanie zasobami ziemi w Polsce - aspekty teoretyczne i praktyczne (Land Resources Management in Poland - Theoretical and Practical Aspects). Wydawnictwo Uniwersytetu Ekonomicznego we Wrocławiu. Wrocław.

Szymańska, J. (2013). Ceny ziemi rolniczej w obrocie prywatnym w opinii respondentów z województwa dolnoślaskiego (Prices of Agricultural Land in Private Trade in the Opinion of Respondents from Dolnoślaskie Province). Roczniki Naukowe SERiA, 15(3), 339-343.

Szymańska, J. (2014). Ziemia w agrobiznesie jako podstawowy zasób i środek produkcji reprezentujący warunki przyrodnicze (Land in Agribusiness as a Basic Resource and Means of Production Representing Natural Conditions). W: S. Urban (red.). Agrobiznes i biobiznes. Teoria i praktyka. Wrocław: Wydawnictwo Uniwersytetu Ekonomicznego we Wrocławiu.

Tańska-Hus, B. (2009). Dzierżawa rolnicza w Polsce na przestrzeni wieków (Agricultural Lease in Poland over the Centuries). Wydawnictwo Uniwersytetu Przyrodniczego we Wrocławiu. Wrocław.

Tarnowska, A. (2014). Zmiany zasobów produkcyjnych rolnictwa krajów Unii Europejskiej w latach 2005-2012 (Changes in Agricultural Production Resources of European Union Countries in 2005-2012). W: A. 
Olszańska (red.). Agrobiznes w teorii i w praktyce (s. 146-156). Wrocław: Wydawnictwo Uniwersytetu Ekonomicznego we Wrocławiu.

Urban, S. (2006). Konkurencja na rynku ziemi rolniczej (Competition on the agricultural land market). Prace Naukowe Akademii Ekonomicznej we Wroctawiu, 1118, 459.

Zadura, A. (2005a). Europejski rynek ziemi rolniczej. Rynek ziemi rolniczej. Analizy Rynkowe (European Agricultural Land Market. Agricultural Land Market. Market Analysis), 8. Warszawa: IERiGŻ-PIB.

Zadura, A. (2005b). Zarządzanie gruntami rolnymi w krajach Europy Środkowo-Wschodniej (Agricultural Land Management in the Countries of Central and Eastern Europe). Warszawa: IERiGŻ-PIB.

Zadura, A. (2009). Aktualne problemy rynku ziemi rolniczej w państwach europejskich. Rynek ziemi rolniczej. Analizy Rynkowe (Current Problems of the Agricultural Land Market in European Countries. Agricultural Land Market. Market Analysis), 12. Warszawa: IERiGŻ-PIB.

Zadura, A. (2010). Aktualne problemy rynku ziemi rolniczej w państwach europejskich. Rynek ziemi rolniczej. Analizy Rynkowe (Current Problems of the Agricultural Land Market in European Countries. Agricultural Land Market. Market Analysis), 13. Warszawa: IERiGŻ-PIB.

Do cytowania / For citation:

Szymańska J. (2019). Sytuacja na rynku ziemi rolniczej w wybranych krajach Europy ŚrodkowoWschodniej (wybrane problemy). Problemy Rolnictwa Światowego, 19(3), 97-107;

DOI: $10.22630 /$ PRS.2019.19.3.50

Szymańska J. (2019). The Situation on the Market of Agricultural Land in Selected Countries of Central and Eastern Europe (in Polish). Problems of World Agriculture, 19(3), 97-107;

DOI: $10.22630 /$ PRS.2019.19.3.50 